\title{
Optimization of ISSI Stock Portfolio using Single Index Models in 2013-2017
}

\author{
Firsty Dzanurrahmana Zein1, Khurul Aimmatul Umah, Khalwat Asyaria1, \\ Sri Herianingrum¹, A. Syifaul Qulub ${ }^{1}$, and Sylva Alif Rusmita ${ }^{2}$ \\ ${ }^{1}$ Student Postgraduate Science of Islamic Economics, Airlangga University, Indonesia \\ ${ }^{2}$ Lecturer Faculty of Economic and Business, Airlangga Universtity, Indonesia
}

\section{Introduction}

\subsection{Background}

Corresponding Author:

Firsty Dzanurrahmana Zein

firstydzanurrahmana@gmail.com

Received: 10 February 2019

Accepted: 14 March 2019

Published: 28 March 2019

Publishing services provided by Knowledge E

(c) Firsty Dzanurrahmana Zein et al. This article is distributed under the terms of the

Commons Attribution License, which permits unrestricted use and redistribution provided that the original author and source are credited.

Selection and Peer-review under the responsibility of the ICIEBP Conference Committee.

\section{S OPEN ACCESS}

The function of the stock price index is an indicator of profit for investors, as a formation facility passive portfolio, as a tool for calculating systematic risk, namely risk that cannot be mitigated through risk management, including diversification, as a means of finding investment opportunities, and for viewing economic developments, as well as a means of developing derivative investment instrument products. The risk in question is seen from how much price changes an effect deviates from changes in overall stock prices (Triharyanto, 2013). When someone decides to invest in shares, it will expect returns future as profits (Yuniarti, 2007).

Fatwa of the National Sharia Council of the Indonesian Ulema Council No. 20 / DSNMUI / IX / 2000 concerning Investment in Sharia Mutual Funds, which concludes that stock investment in Islam is permissible. One of the sharia shares is shares listed on the ISSI because this index includes more shares, namely 366 shares (OJK, 2018). Large indexes in the formation of optimal portfolios can diversify risk to the maximum because more shares are included in the calculation.

Risk diversification is very important for investors because it can minimize risk without having to reduce the return received, in several ways, such as forming a portfolio containing many assets, randomly or diversified by the Markowitz method (Jogiyanto, 2010: 279). If investors are rational, they will choose the optimal portfolio, namely the portfolio with the best combination of return expected and risk (Jogiyanto, 2010: 88).

The reason for taking a single index model as a research study, first is a simplification of the Markowitz and Capital Asset Pricing Model (CAPM). Second, a single index model is based on stock prices, which will experience price increases if the stock price index 
rises. Also applies to the opposite law (Husnan, 2003; Jogiyanto, 2010: 339). Third, the widespread use of the investment product index as an investment guide for investors in determining investment decisions such as ISSI. So, researchers want to know how the optimal portfolio formation that was formed in 2013-2017 and the limited research that discusses the formation of an optimal portfolio at the ISSI.

\section{Theory Basis}

\subsection{Return}

Return is a return on income received from an investment plus a change in market prices, usually expressed as a percentage of the initial investment market price (Van Horne, 1997). Actual return is the rate of return that has been obtained by previous investors. Expected return is the level of return anticipated by investors in the future and is calculated based on the average derived from a distribution return (Elton and Gruber, 1995).

\subsection{Single index model}

Single Index Model was first put forward by William Sharpe in 1963. This model can determine whether a stock entered into the optimal portfolio or not using a unique ranking criterion. Shares will be sorted by performance measured using an excess ratio return to risk, so that if a stock enters an optimal portfolio, then stocks with a higher ranking will also enter into the portfolio (Bakhoirudin, 2015).

\subsection{Previous research}

Sarker, (2013) analyse an optimal portfolio by using Markowitz model. For this purpose the monthly closing prices of 164 companies listed in Dhaka Stock Exchange (DSE) and DSE all share price index for the period of July 2007 to June 2012 have been considered. The proposed method formulates an efficient set, selects portfolio having excess return to standard deviation ratio satisfying the constraint that the sum of proportions invested in the assets equals one. The optimum portfolio consists of twenty stocks selected out of 164 stocks, giving the return of $6.48 \%$.

Ivanova and Dospatliev (2017) provide a practical study of Markowitz model on the Bulgarian stock market from 2013 to 2016 . The significance of this study arises from 
the fact that although Markowitz model has been widely used by investors worldwide, its application on Bulgarian stock market is still relatively limited. From the data inputs which are weekly closing prices of 50 stocks traded on Bulgarian Stock Exchange between January 2013 and December 2016, efficient frontiers in addition to optimal portfolios are determined on the basis of Markowitz theory.

Kulali (2016) had test Markowitz mean-variance approach on Istanbul Stock Exchange (BIST). 252 days of data belonging a year of 2015 are analyzed. In empiricial analysis, The Author followed meanvariance model and created many portfolios. The model adjusted them as a minimum variance for a given expected return. Investors choose any of them as their risk preferences. Because they are all efficient. The Author optimal portfolio is constructed by eight assets with different weights. It provides more return comparing with aportfolio with equal shares of ten stocks.

\section{Research Method}

The approach of this study is a quantitative descriptive approach. The data analysis technique uses descriptive statistics. The data sample used is companies that are listed and actively traded on the Indonesian Syariah Stock Index (ISSI) from 2013-2017. Samples were taken by methods non probability sampling and purposive sampling. The required data is in the form of secondary data, namely: issuer's stock price data at the closing price at the end of the month, Composite Stock Price Index (CSPI), Indonesian Sharia Stock Index (ISSI), yield rate of the 2013- Bank Indonesia Sharia Certificate 2017. The identification of variables in this study is the optimal portfolio using a single index method, ERB $>C^{*}$.

The operational definition in this study is (Jogiyanto, 2010: 20-239):

\subsection{Optimal portfolio}

The formation of an optimal portfolio is based on the excess return to beta (ERB) of each security. ERB is the excess return of securities on asset return a risk-free(risk free rate)as measured by beta. Excess Return to Beta is calculated by:

$$
\mathrm{ERBi}=\frac{E\left(R_{i}-R_{f}\right)}{\beta_{i}}
$$

$E R B i=$ Excess Return to Beta stock to $i$

$\mathrm{Rf}=$ Risk Free Rate of Return

$E(R i)=$ Return of expectation from investment stock $i$ 
$\beta i=$ Beta stock to $i$

Before calculating ERB, must look for:

1. Realized return individual (Rit):

$$
\mathrm{Rit}=\frac{R_{t}-R_{t-1}+D_{t}}{R_{t-1}}
$$

$\mathrm{Ri}=$ Return realized of stock realization to $\mathrm{i}$ period $\mathrm{t}$

$\mathrm{Rt}=$ Stock price in period $\mathrm{t}$

$\mathrm{R}_{t-1}=$ Stock price in the previous period

$D t=$ Share dividend paid in period $t$

2. Expected Return (E(Ri))

$$
\mathrm{E}(\mathrm{Ri})=\frac{\sum_{i}^{n=1} R_{i t}}{n}
$$

$E(R i)=$ Expected return from stock $\mathrm{i}$

Rit $=$ Return on stock realization i period $t$

$\mathrm{n}=$ Number of observations

3. Return Market $\left(\mathrm{R}_{m}\right)$

$$
R_{m}=\frac{\text { ISSIt }- \text { ISSIt }-1}{\text { ISSIt }-1} \quad E\left(R_{m}\right)=\frac{\sum R_{m}}{n}
$$

$\mathrm{Rm}=$ Return Market period $\mathrm{t}$

$\mathrm{ISSI}_{t=} \mid \mathrm{SSI}$ in period $\mathrm{t}$

$\mathrm{ISSI}_{t-1}=\mathrm{ISSI}$ in the previous period

$E(R m)=$ Expected return market

$\mathrm{n}=$ Time of observation

4. Standard deviation ( $\sigma)$

Calculation of risk from return realization of each stock with the formula:

$$
\sigma=\sqrt{\sum_{i=1}^{n} \frac{R_{i}-E\left(R_{i}\right)^{2}}{n}}
$$

$\sigma=$ stock standard deviation i

$\mathrm{Ri}=$ return stock realized $\mathrm{i}$

$E(R i)=$ expected return stock $i$ 
$\mathrm{n}=$ total return stock realized $\mathrm{i}$

$$
\sigma_{m}=\sqrt{\sum_{i=1}^{n} \frac{R_{m t}-E\left(R_{m}\right)^{2}}{n}}
$$

$\sigma_{m}=$ standard market deviation

$\mathrm{R}_{m t}=$ Return market to $\mathrm{t}$

$E\left(R_{m}\right)=$ Expected return market

$\mathrm{n}=$ Number returns of stock realization $\mathrm{i}$

5. Variance $\left(\sigma^{2} \mathrm{i}\right)$

As a measure of the risk of the expected return of each stock, with the formula:

$$
\begin{aligned}
\sigma^{2 i} & =\sum_{i=1}^{n} \frac{R_{i}-E\left(R_{i}\right)^{2}}{n} \\
\sigma^{2 m} & =\sum_{i=1}^{n} \frac{R_{m}-E\left(R_{m}\right)^{2}}{n}
\end{aligned}
$$

6. Variance $\left(\sigma_{e i}\right)$

Variant of residual error stocki which is also a unique or non-systematic risk (Tandelilin, 2010: 169)

$$
\sigma e i(i)=\sigma_{i}^{2}-\left(\sigma_{m}^{2} \cdot(\alpha i)^{2}\right)
$$

$\sigma_{e i}(\mathrm{i})=$ Variance ei stock $\mathrm{i}$

$\sigma^{2} \mathbf{i}=$ variance Stocki

$\sigma_{m}^{2}=$ variance Market

$\alpha i=$ Alpha stock $\mathrm{i}$

7. Beta $(\beta i)$

Beta to reduce the number of variables that need to be estimated (Husnan, 2003).

$$
\beta i=\frac{\sigma_{i, m}}{\sigma^{2} m}
$$

$\beta i=$ Beta stock $i$

$\sigma i, m=$ Covariance of returns stocki with return market

$\sigma_{m}^{2}=$ Variance return market 


\section{Alpha $(\alpha)$}

Calculation return of stock realization i with return market in a certain period of time (Tandelilin, 2010: 132)

$\alpha i=R m-\beta i$

$\alpha i=$ Alpha stock to $i$

$\beta i=$ Beta stock to $i$

$\mathrm{R}_{m}=$ return Market

9. Ai value and $\mathrm{Bi}$

$$
\begin{gathered}
A i=\frac{\left[E\left(R_{i}\right)-R_{f}\right], \beta_{i}}{\sigma_{e i}} \\
B i=\frac{\beta_{i}^{2}}{\sigma_{e i}}
\end{gathered}
$$

$E(R i)=$ Expected return stock $i$

$\mathrm{Rf}=$ Risk free rate of return

$\beta i=$ Stock beta $i$

$\sigma_{e i}=$ Variance of shares (unique risk)

10. Cut - off - Point $\left(C^{*}\right)$

Results for market variance and return premium on error variance stock and is a measure for stocks included in the optimal portfolio

$$
C i=\frac{\sigma^{2} m \sum_{j=1}^{i} A_{i}}{1+\sigma^{2} m \sum_{j=1}^{i} B_{i}}
$$

$\sigma_{m}^{2}=$ Variance realized return market

11. Proportion of funds per share by calculating the percentage of each share selected in the formation of an optimal portfolio

$$
\begin{gathered}
W_{i}=\frac{X_{i}}{\sum_{i=1}^{n} X_{i}} \\
X_{i}=\frac{\beta_{i}}{\sigma_{e i^{2}}}(E R B-C *)
\end{gathered}
$$

$\mathrm{W}_{i}=$ Large percentage of funds invested in stock $\mathrm{i}$

$\mathrm{X}_{i}=$ Proportion of stock $\mathrm{i}$

$\mathrm{C}^{*}=$ Value $\mathrm{C}_{i}$ is greatest 
12. Calculate portfolio return and expected return, with:

$$
\boldsymbol{R}_{p}=\sum_{i=1}^{n} W_{i} \boldsymbol{R}_{i}
$$

$R_{p}=$ Return portofolio

$$
E\left(R_{p}\right)=\alpha_{p}+\beta_{p} R_{p},
$$

where

$$
\begin{aligned}
& \alpha_{p}=\sum_{i=1}^{n} W_{i} \alpha_{i} \\
& \beta_{p}=\sum_{i=1}^{n} W_{i} \beta_{i}
\end{aligned}
$$

13. Calculate portfolio risk, with:

$$
\begin{gathered}
\sigma_{p}^{2}=\beta_{p}^{2} \sigma_{m}^{2}+\sum_{i=1}^{n} W_{i}^{2} \sigma_{e i}^{2} \\
\sigma_{p}=\sqrt{\beta_{p}^{2} \sigma_{m}^{2}+\sum_{i=1}^{n} W_{i}^{2} \sigma_{e i}^{2}}
\end{gathered}
$$

$\sigma_{p}^{2}=$ Varian portofolio

$\sigma_{p}=$ Standar deviasi portofolio

Portfolio variance

$\sigma_{p}=$ Portfolio standard deviation

14. Portfolio Performance

After the selected stock forming portfolio for the period 2013-2017, then its performance is measured in $\mathbf{2 0 1 8}$ which is then compared with its market performance with the method Sharpe. The market is described by ISSI and risk free is described by Bank Indonesia Syariah Certificates. Portfolio performance is measured by comparing the portfolio risk premium with portfolio risk expressed by standard deviation (total risk) (Halim, 2005: 51).

$$
\mathrm{Spi}=\frac{R p i-R f}{S D p i}
$$

Spi $=$ Index Sharpe Portfolio

Rpi $=$ Average Portfolio Yield $\mathrm{i}$

$\mathrm{Rf}=$ Average SBIS Yield

SDpi $=$ Standard Deviation from Portfolio Yield $\mathrm{i}$

Rpi - Rf = Portfolio Risk Premium 


\section{Description of Research Results}

\subsection{Establishment of optimal portfolio}

1. Realized return, expected return standard deviation and variance,error variance stock, market and SBIS.

Based on the calculation of 224 samples of Islamic stocks. In table 1, the return highest expectation of $E(\mathrm{Ri})$ is owned by SMDR with a value of 0.1134 , while the lowest return of expectation $E(R i)$ is owned by the MERK with a value of -0.3076 . Shares that have a return positive expectation are good stocks and have the opportunity to be able to provide returns high.

Standard deviation and variance highest is MERK with a value of 2.5831 and 6.6723 , while the lowest standard deviation is SRSN with a value of 0.0036 . The variance lowest is AALI with a value of -0.0190 . The higher the standard deviation and variance value, the higher the risk value and vice versa. return Expectation, standard deviation, variance SBIS that reflects risk-free assets (Rf) because Bank Indonesia is guaranteed to pay its obligations at maturity.

In table 2, expectations, standard deviations, variance market are respectively $0.0048,0.0346$, and 0.0012 . Return positive value markets means investing in shares in ISSI the period 2013-2017 benefit investors. Whereas the return expected, standard deviation, variance are SBISworth $0.0063,0.0151$ and 0.0002 .

2. Beta, alpha and error variance stock

Beta risk coefficients reflect the sensitivity of a stock to change markets with greater beta $(\beta>1)$ are increasingly sensitive to market changes (stocks that are increasingly at risk). Including systematic risk that cannot be eliminated even by forming a portfolio. If the alpha value is negative, it means that it is not included in the optimal portfolio. Shares is negative means the risk of such shares is greater than return of this.

Error variants are unique risks or non-systematic risks of a stock. In table 3, shares with the highest beta value are SONA, which is 4,2501, the lowest value is SPMA which is $-11,5278$. The highest alpha value is SMDR of 0.1095 and the lowest value is MERK of -0.2707 . The value error variance highest is BRAND of 6.6026 and the lowest value is ADES of -0.1095 .

3. Optimal Portfolio Formation 
First, calculate the value of excess return to beta (ERB). Shares with a negative ERB value means that the stock has a stock return below the risk-free rate of return. ERB calculations require data on risk-free asset returns using the average monthly SBIS reward rate during the study period and the average monthly SBIS reward rate of $0.0063 \%$. The ERB calculation results show that there are 74 issuers whose ERB is positive and there are 150 ERB issuers with negative values which are automatically excluded from the optimal portfolio candidate list. Then look for the Cut Off Rate (Ci) value. Optimal portfolio candidates if the ERB value is $>C^{*}$. In table 4 , the highest $\mathrm{Ci}$ value is 0.0346 in the lowest INCY and $\mathrm{Ci}$ shares of -0.011 in EKAD shares. The biggest ERB value is 0.1343 in the lowest SMDR and ERB shares of 0.0002 in INDY shares. Criteria that fulfill the optimal portfolio formation are 58 shares.

4. Determination of Proportion of Funds

The proportion of funds (Wi) invested in each portfolio share is shown in table 5 .

\section{Calculation Expected Return and Portfolio Risk}

In table 6 , the formed portfolio gives an expected return of $2,62 \%$ per month or $31.5 \%$ per year. The value of systematic risk relative to market risk (beta) of the portfolio is around 0.7855 . The portfolio standard deviation or risk value is 0.0275 or around $2.75 \%$.

\section{Optimal Portfolio Performance}

In table 7, the performance of the optimal portfolio of shares listed in the ISSI 2018 with a index sharpe of -0.495 , with return -0.022 and standard deviation of 0.054 . The market in research is ISSI. The calculation results of 2018 market performance with sharpe index are -0.708 with return -0.012 and standard deviation of 0.024 .

\section{Discussion}

\subsection{Optimal portfolios formed 2013-2017}

To find out how well the portfolio is produced, it is necessary to compare it with other stock indices, namely JII, ISSI, and IHSG. Comparison of portfolio performance with several indices based on a comparison of returns monthly during the 2013-2017 period. 
TABLE 1: Expected Return, Standar Deviation, Variance Individual Stocks (Source: prepared by the authors).

\begin{tabular}{|c|c|c|c|c|c|c|c|c|c|c|c|c|c|c|c|}
\hline CODE & i) & $\sigma \mathrm{i}$ & $\sigma^{2}{ }_{i}$ & & (Ri) & $\sigma \mathrm{i}$ & $\sigma_{i}^{2}$ & E & $\mathbf{E}(\mathbf{R i})$ & $\sigma \mathbf{i}$ & $\sigma_{i}^{2}$ & DE & $\mathbf{E}(\mathbf{R i})$ & $\sigma \mathrm{i}$ & $\sigma_{i}^{2}$ \\
\hline AALI & 0036 & & 0,0190 & EW & 0027 & $\overline{6}$ & 0067 & $\mathrm{BLV}$ & $-0,0013$ & 2145 &, 0460 & RANC & $-0,0137$ & 25 & \\
\hline & & & & & & & & & & & & & & & \\
\hline & & & & & & & & & & & & & & & \\
\hline & & & & & & & & & & & & & & & \\
\hline & & & & & & & & & & & & & & & \\
\hline & & & & & & & 492 & & & & 96 & & & & \\
\hline AIMS & & & 777 & & & & 0336 & & & & 0321 & & & & 0042 \\
\hline AISA & & & 0196 & & & & 0108 & & & & 0094 & & & & 0313 \\
\hline & & & 6613 & AD & & & 0045 & & & & 0134 & & & & 0077 \\
\hline AKRA & & & 0076 & & & & 0195 & & & & 0236 & & & &, 0056 \\
\hline ALKA & & & 0,1224 & $\Gamma \mathrm{Y}$ & & & 0029 & & & & 0119 & & & &, 0326 \\
\hline & & & 0,0051 & $\mathrm{DE}$ & & & 0115 & & & & 0270 & & & &, 0103 \\
\hline & & & 0799 & & & & 0259 & & & & 0179 & & & &, 0069 \\
\hline & & & 0,0209 & & & & 0088 & & & & 0211 & & & &, 0877 \\
\hline & & & 0,0111 & & & & 0203 & & & & & & & & \\
\hline & & & & & & & 0 & & & & & & & & \\
\hline & & & & & & & & & & & & & & & \\
\hline & & & & & & & & & & & & & & & \\
\hline $\mathrm{Al}$ & & & 82 & & & & 88 & & & & & & & & \\
\hline A & & & 144 & & & & 0107 & & & & 12 & & & & \\
\hline $\mathrm{A}$ & & & 43 & & & & 0090 & & & & 00 & & & & \\
\hline $\mathrm{A}$ & & & 30 & & & & 220 & & & & 0109 & & & & \\
\hline & & & 194 & & & & 0133 & & & & $0 \%$ & & & & \\
\hline $\mathrm{B}$ & & & 196 & & & & 0 & & & & & & & & 54 \\
\hline BATA & & & 995 & & & & 0141 & & & & 0039 & & & & 765 \\
\hline & & & 112 & & & & 00 & & & & & & & & 682 \\
\hline BBRM & & & 127 & & & & 52 & & & & & & & & 000 \\
\hline BCIP & & & 0,0613 & & & & 0,0261 & & & & & & & &, 7906 \\
\hline BEST & & & 225 & & & & & & & & & & & & \\
\hline & & & & & & & & & & & & & & & \\
\hline & & & & & & & & & & & & & & & \\
\hline & & & & & & & & & & & & & & & \\
\hline & & & & & & & & & & & & & & & \\
\hline & & & & & & & & & & & & & & & \\
\hline & & & & & & & & & & & & & & & \\
\hline & & & & & & & 66 & & & & & & & & \\
\hline BSDE & & & & & & & 98 & & & & & & & & \\
\hline & & & & & & & 33 & & & & & & & & \\
\hline & & & & & & & 49 & & & & 190 & & & & \\
\hline BTC & & & & & & & 0228 & & & & - & & & &, 0218 \\
\hline BUDI & & & 0054 & & & & 0371 & & & & 0108 & & & &, 0138 \\
\hline & & & 31 & & & & 0394 & & & & & & & & 0,0023 \\
\hline & & & & & & & -7 & & & & & & & &, 0077 \\
\hline & & & 146 & & & & 0029 & & & & & & & & 091 \\
\hline CASS & & & 0056 & & & & 0071 & & & & & & & &, 0109 \\
\hline CEKA & & & 0981 & & & & 75 & & & & 50 & & & & 212 \\
\hline $\mathrm{Cl}$ & & & & & & & & & & & & & & & 551 \\
\hline CKRA & & & & & & & 202 & & & & 246 & & & &, 0032 \\
\hline CLPI & -0 & & 39 & & & & 36 & & & & 127 & & & & 0,0214 \\
\hline CMNP & 0,0 & & 0,0131 & & & & 0,0067 & $\mathrm{O}$ & & & 0209 & & & & 0,0173 \\
\hline CNKO & - & & & & & & 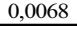 & & & & & $\mathrm{PO}$ & & & 0,0433 \\
\hline & & & & & & & & & & & & & & & \\
\hline & & & & & & & & & & & & & & & \\
\hline 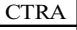 & & & 94 & & & & & & & & & & & & \\
\hline & & & & & & & & & & & & & & & \\
\hline DART & . & 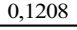 & 0,0146 & KBLM & & & 0,0354 & & & & & & & & , \\
\hline
\end{tabular}

TABLE 2: Expected Return, Standard Deviation, Variance Markets and SBIS (Source: processed by the author).

\begin{tabular}{|l|c|c|}
\hline & ISSI (Rm) & SBIS (Rf) \\
\hline $\mathbf{E}(\mathbf{R i})$ & 0,0048 & 0,0063 \\
\hline $\boldsymbol{\sigma i}$ & 0,0346 & 0,0151 \\
\hline $\boldsymbol{\sigma}^{\mathbf{2}}{ }_{\mathbf{i}}$ & 0,0012 & 0,0002 \\
\hline
\end{tabular}

The results of the comparison of performance between the portfolio and the three stock indices are shown in graph 1.

Based on graph 1, shows that the portfolio performance produced tends to be better than the three other stock indices. The portfolio line in the graph is almost always higher 
TABLE 3: Beta, Alpha, and Variance Error (Source: processed by the author).

\begin{tabular}{|c|c|c|c|c|c|c|c|c|c|c|c|c|c|c|c|}
\hline & $\beta \mathbf{\beta}$ & & & & $\beta \mathbf{i}$ & & & & & & & DE & $\beta \mathbf{\beta i}$ & $\boldsymbol{\alpha i}$ & ei \\
\hline$\overline{A L I}$ & 0,4600 & 0059 & 0,010 & & 2 & & 0,0067 & & 1,35 & 0,0079 & 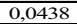 & & 1,02 & 0,0187 & $\overline{0,00}$ \\
\hline BBA & 0658 & 084 & 0044 & GIK & 3523 & 0,0321 & 0369 & DSI & 1,2492 & 0,0044 & 0,0414 & RICY & 0,3049 & 0,0032 & 0,0024 \\
\hline & 5 & & & & 26 & 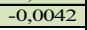 & & & 48 & & & & & & 087 \\
\hline & & & & & & & & & & & & & & & \\
\hline $\mathrm{GG}$ & 764 & 013 & 1 & & 923 & 0014 & 295 & $\mathrm{BF}$ & 55 & & & $\mathrm{DA}$ & 0,0776 & 050 & 0220 \\
\hline ADRO & 8365 & & & & 2597 & 0142 & & & & & & &, 7945 & 0,0028 & \\
\hline & & & & & & & & & & & & & & & \\
\hline AISA & 201 & 27 & 99 & & 1,0618 & $-0,0029$ & 094 & G & 515 & 52 & & $\mathrm{ME}$ & 0,9683 & 274 & 302 \\
\hline & & & & & & & & & & & & & & & \\
\hline & 361 & & & & & & & & & & & & & & 051 \\
\hline & $-0,0139$ & 0269 & 1224 & & 0335 & $-0,0$ & 29 & & & $-0,0$ & & & 1,1806 & & 0,0309 \\
\hline & & & & & & & & & & & & & & & \\
\hline & 600 & 9 & & & & & & & & & & & & & 066 \\
\hline & & & & & & & & & & & & & & & \\
\hline & 52 & & & & & & & & & & & & & & \\
\hline $\mathrm{A}$ & 3043 & 01 & & & 90 & & & & & & & & & & \\
\hline & & & & & & & & & & & & & & & \\
\hline & & & & & & & & & & & & & & & \\
\hline $\mathrm{AF}$ & 0,9 & 43 & & & 31 & $-0,0$ & & & & & & & & & \\
\hline & & & & & & & & & & & & & & & \\
\hline & & & & & & & & & & & & & & & \\
\hline & & & & & & & & & & & & & & & \\
\hline & & & & & & & & & & & & & & & \\
\hline & & & & & & & & & & & & & & & \\
\hline & & & & & & & & & & & & & & & \\
\hline & & & & & & & & & & & & & & & \\
\hline & & & & & & & & & & & & & & & \\
\hline & & & & & & & & & & & & & & & \\
\hline & & & & & & & & & & & & & & & \\
\hline & & & & & & & & & & & & & & & \\
\hline & & & & & & & & & & & & & & & \\
\hline $\mathrm{BK}$ & & & & & & & & & & & & & & & \\
\hline & & & & & & & & & & & & & & & \\
\hline & & & & & & & & & & & & & & & \\
\hline & & & & & & & & & & & & & & & \\
\hline & & & & & & & & & & & & & & & \\
\hline BSDE & 1, & & 0 & & 92 & & & & & & & & & & \\
\hline & & & & & & & & & & & & & & & 332 \\
\hline & & & & & & & & & & & & & & & 032 \\
\hline & & & & & & & & & & & & & & & \\
\hline BUDI & 0 , & 00 & 0,00 & & & $-0,0$ & 3 & IS & & 0,0 & 90 & & & 06 & 138 \\
\hline & & & & & & & & & & & & & & & 0,0023 \\
\hline BUVA & 0,4825 & & & & 4 & 0 , & & & & & & & & & 0065 \\
\hline $\mathrm{AN}$ & 373 & & & & & $-0,0$ & 69 & & $-0,0740$ & 93 & & & & & 0,0072 \\
\hline & & & & & & & & & & & & & & & \\
\hline & & & & & & & & & & 75 & & & & 13 & 211 \\
\hline CENT & 0,9653 & & & & & & & & & & & & & & 048 \\
\hline CKRA & 1,0332 & 0272 & 0,0288 & & 2086 & $-0,0129$ & 0185 & & 6811 & 0,0045 & 12 & VR & 6483 & 0,0142 & 0,0027 \\
\hline & & & & & & & & & & & & & & & 189 \\
\hline & & & & & & & & & & & & & & & \\
\hline & & & & & & & & & & & & & & & \\
\hline$\overline{\mathrm{C}}$ & 1,8671 & -0 & 0 & & & -0 , & & & & 74 & & & & & 0121 \\
\hline CSAP & 0,6761 & & 0, & & & 0,0 & 57 & $\mathrm{ON}$ & & 0,0 & 00 & & & & 18 \\
\hline & & & & & & & & & & & & & & & \\
\hline & & & & & & & & & & & & & & & \\
\hline & & & & & & & & & & & & & & & \\
\hline
\end{tabular}

than the other three stock indices. In table 8, the resulting portfolio has the average return highest among the three other stock indices, which is $2.62 \%$ much higher than ISSI (0.48\%), JII (0.06\%), and IHSG (0,67\%). At the level of risk, the lowest risk JII index with a standard deviation value of $0.49 \%$, rather than the $\mathrm{ISSI}$ of $3.46 \%, \mathrm{JCl}$ shares of $3.5 \%$ and portfolio shares of $2.75 \%$. For the level of portfolio risk, although not the lowest, at least the risk level is still below the level of stock index risk and the market risk (ISSI).

Following are comparisons of return and risk portfolio, market, and SBIS in 2013-2017

The average return portfolio is 0.026 which is higher than the return market which is 0.0048 and the return risk-free(SBIS) is 0.0063 . So by forming a portfolio, it gives return a higher than not forming a portfolio.risky portfolio with a value of 0.0275 , market 0.0346 , and SBIS 0.0151. This proves that by forming a portfolio that provides higher profits with a lower level of risk than market risk. This study is in accordance with the opinion of 
TABLE 4: Comparison of ERB with Ci (Source: processed by the author).

\begin{tabular}{|c|c|c|c|c|c|c|c|c|c|c|c|}
\hline CODE & ERB & Ci & CODE & ERB & Ci & CODE & ERB & Ci & CODE & ERB & Ci \\
\hline ACES & 0,0017 & $-0,0004$ & GOLD & 0,0043 & $-0,0020$ & MKPI & 0,0941 & $-0,0017$ & SMRU & 0,0052 & 0,004 \\
\hline AIMS & 0,0346 & $-0,0090$ & HITS & 0,0880 & $-0,0039$ & MYOR & 0,0319 & 0,011 & SMSM & 0,0298 & 0,0003 \\
\hline AKKU & 0,0173 & $-0,0022$ & IBST & 0,0062 & $-0,0053$ & MYRX & 0,0035 & 0,0093 & SSIA & 0,0088 & 0,0003 \\
\hline AKRA & 0,0050 & $-0,0016$ & ICBP & 0,0083 & $-0,0082$ & NIKL & 0,0284 & 0,0126 & STAR & 0,0098 & 0,0012 \\
\hline ARTA & 0,0054 & $-0,0044$ & IGAR & 0,0016 & $-0,0027$ & NIPS & 0,0136 & 0,0101 & STTP & 0,0877 & 0,0007 \\
\hline BAYU & 0,0336 & $-0,0075$ & IIKP & 0,0097 & 0,0053 & PANR & 0,0289 & 0,0149 & TBLA & 0,0172 & 0,0137 \\
\hline BISI & 0,0085 & $-0,0042$ & INAF & 0,0141 & 0,0058 & PGLI & 0,0390 & 0,0067 & TBMS & 0,0127 & 0,0125 \\
\hline BRNA & 0,0050 & $-0,0051$ & INAI & 0,0407 & 0,0074 & PTPP & 0,0100 & 0,0127 & TLKM & 0,0120 & 0,0113 \\
\hline BTEK & 0,0077 & 0,0021 & INCI & 0,0044 & 0,0346 & PTSN & 0,0032 & 0,0099 & TOTL & 0,0352 & 0,0172 \\
\hline CEKA & 0,0157 & $-0,0002$ & INDY & 0,0002 & 0,0052 & PWON & 0,0061 & 0,0068 & TPIA & 0,1233 & 0,0116 \\
\hline CSAP & 0,0103 & $-0,0091$ & INPP & 0,0075 & 0,0085 & RAJA & 0,0036 & 0,0108 & TURI & 0,0002 & 0,0142 \\
\hline CTTH & 0,0050 & 0,0030 & ITMA & 0,0504 & 0,0034 & SAME & 0,0267 & 0,0051 & ULTJ & 0,0180 & 0,0074 \\
\hline DSFI & 0,0111 & $-0,0023$ & JRPT & 0,0008 & 0,0029 & SCCO & 0,0114 & 0,0025 & UNTR & 0,0140 & 0,0163 \\
\hline EKAD & 0,0043 & $-0,0110$ & KAEF & 0,0082 & 0,0064 & SDMU & 0,0095 & 0,0077 & UNVR & 0,0170 & 0,0083 \\
\hline ELSA & 0,0175 & $-0,0003$ & KBLI & 0,0027 & 0,0053 & SIMA & 0,0298 & 0,0115 & VOKS & 0,0189 & 0,0141 \\
\hline EMDE & 0,0321 & $-0,0005$ & KBLM & 0,0054 & 0,0053 & SIPD & 0,0055 & 0,0076 & WAPO & 0,0085 & 0,0133 \\
\hline FISH & 0,0019 & $-0,0062$ & KLBF & 0,0013 & 0,0022 & SKBM & 0,0466 & 0,0091 & WICO & 0,0264 & 0,0149 \\
\hline FMII & 0,0174 & $-0,0021$ & KOIN & 0,0093 & 0,0075 & SMDR & 0,1343 & 0,0082 & WSKT & 0,0144 & 0,0172 \\
\hline GEMA & 0,0523 & 0,0024 & LPPF & 0,0072 & $-0,0009$ & & & & & & \\
\hline
\end{tabular}

TABLE 5: Calculation of Proportion of Funds (Wi) (Source: processed by the author).

\begin{tabular}{|c|c|c|c|c|c|c|c|c|c|c|c|}
\hline CODE & $\mathbf{X i}$ & $\mathbf{W i}$ & CODE & $\mathbf{X i}$ & $\mathbf{W i}$ & $\mathbf{C O D E}$ & $\mathbf{X i}$ & $\mathbf{W i}$ & $\mathbf{C O D E}$ & $\mathbf{X i}$ & $\mathbf{W i}$ \\
\hline ACES & 0,274 & $0,60 \%$ & EMDE & 0,621 & $1,35 \%$ & KOIN & 0,044 & $0,10 \%$ & SMRU & 0,012 & $0,03 \%$ \\
\hline AIMS & 0,142 & $0,31 \%$ & FISH & 0,320 & $0,70 \%$ & LPPF & 0,736 & $1,60 \%$ & SMSM & 0,441 & $0,96 \%$ \\
\hline AKKU & 0,301 & $0,66 \%$ & FMII & 0,552 & $1,20 \%$ & MKPI & 4,480 & $9,77 \%$ & SSIA & 0,020 & $0,04 \%$ \\
\hline AKRA & 0,812 & $1,77 \%$ & GEMA & 0,955 & $2,08 \%$ & MYOR & 1,572 & $3,43 \%$ & STAR & 0,497 & $1,08 \%$ \\
\hline ARTA & 0,225 & $0,49 \%$ & GOLD & 0,228 & $0,50 \%$ & NIKL & 0,318 & $0,69 \%$ & STTP & 1,606 & $3,50 \%$ \\
\hline BAYU & 1,303 & $2,84 \%$ & HITS & 0,892 & $1,94 \%$ & NIPS & 0,201 & $0,44 \%$ & TBLA & 0,298 & $0,65 \%$ \\
\hline BISI & 1,339 & $2,92 \%$ & IBST & 0,144 & $0,31 \%$ & PANR & 1,033 & $2,25 \%$ & TBMS & 0,008 & $0,02 \%$ \\
\hline BRNA & 1,456 & $3,17 \%$ & ICBP & 5,975 & $13,03 \%$ & PGLI & 0,149 & $0,33 \%$ & TLKM & 0,226 & $0,49 \%$ \\
\hline BTEK & 0,188 & $0,41 \%$ & IGAR & 0,162 & $0,35 \%$ & SAME & 0,693 & $1,51 \%$ & TOTL & 0,004 & $0,01 \%$ \\
\hline CEKA & 0,127 & $0,28 \%$ & IIKP & 0,118 & $0,26 \%$ & SCCO & 1,373 & $2,99 \%$ & TPIA & 1,611 & $3,51 \%$ \\
\hline CSAP & 1,075 & $2,34 \%$ & INAF & 0,306 & $0,67 \%$ & SDMU & 0,069 & $0,15 \%$ & ULTJ & 0,813 & $1,77 \%$ \\
\hline CTTH & 0,153 & $0,33 \%$ & INAI & 2,550 & $5,56 \%$ & SIMA & 0,040 & $0,09 \%$ & UNVR & 2,089 & $4,55 \%$ \\
\hline DSFI & 0,357 & $0,78 \%$ & ITMA & 0,139 & $0,30 \%$ & SKBM & 0,139 & $0,30 \%$ & VOKS & 0,132 & $0,29 \%$ \\
\hline EKAD & 4,990 & $10,88 \%$ & KAEF & 0,078 & $0,17 \%$ & SMDR & 0,756 & $1,65 \%$ & WICO & 0,236 & $0,52 \%$ \\
\hline ELSA & 0,491 & $1,07 \%$ & KBLM & 0,006 & $0,01 \%$ & & & & & & \\
\hline
\end{tabular}

Tandelilin (2010: 156) that risk can be controlled by increasing the type of shares in its investment. An investor will most likely not see the whole picture of investment, which may inadvertently cause investment decisions to be bad. So, the need to measure portfolio performance because it is not known how much risk is caused. Based on this 
TABLE 6: Return and Risk of Optimal Portfolio (Source: prepared by the authors).

\begin{tabular}{|c|c|c|c|c|c|c|c|c|c|c|c|c|c|c|c|}
\hline DE & Wi & Ri) & $\beta$ & $\mathrm{ODE}$ & Wi & $\mathrm{E}(\mathbf{R i})$ & $\beta$ & CODE & Wi & $\mathbf{E}(\mathbf{R i})$ & $\boldsymbol{\beta}$ & CODE & Wi & $\mathbf{E}(\mathbf{R i})$ & $\beta$ \\
\hline ACES & $0,60 \%$ & $0,002 \%$ & 0,007 & EMDE & $1,35 \%$ & $0,017 \%$ & 0,003 & KOIN & $0,10 \%$ & $0,001 \%$ & 0,001 & SMRU & $0,03 \%$ & $0,000 \%$ & 0,000 \\
\hline AIMS & $0,31 \%$ & $0,008 \%$ & 0,002 & FISH & $0,70 \%$ & $0,003 \%$ & 0,005 & LPPF & $1,60 \%$ & $0,016 \%$ & 0,023 & SMSM & $0,96 \%$ & $0,015 \%$ & 0,004 \\
\hline $\mathrm{AKKU}$ & $0,66 \%$ & $119 \%$ & 0,006 & FMII & $1,20 \%$ & $0,020 \%$ & 0,010 & MKPI & $9,77 \%$ & $0,332 \%$ & 0,029 & SSIA & $0,04 \%$ & $0,001 \%$ & 0,002 \\
\hline AKRA & $1,77 \%$ & $0,012 \%$ & 0,015 & GEMA & $2,08 \%$ & $0,033 \%$ & 0,004 & MYOR & $3,43 \%$ & $0,087 \%$ & 0,023 & STAR & $1,08 \%$ & $0,011 \%$ & 0,008 \\
\hline ARTA & $49,00 \%$ & $0,003 \%$ & 0,003 & GOLD & $0,50 \%$ & $0,003 \%$ & 0,002 & NIKL & $0,69 \%$ & $0,043 \%$ & 0,016 & STTP & $3,50 \%$ & $0,107 \%$ & 0,010 \\
\hline BAYU & $2,84 \%$ & $0,062 \%$ & 0,015 & \begin{tabular}{|l|} 
HITS \\
\end{tabular} & $1,94 \%$ & $0,532 \%$ & 0,005 & NIPS & $0,44 \%$ & $0,010 \%$ & 0,008 & TBLA & $0,65 \%$ & $0,009 \%$ & 0,004 \\
\hline BISI & $2,92 \%$ & $0,034 \%$ & 0,037 & IBST & $0,31 \%$ & $0,002 \%$ & 0,002 & PANR & $2,25 \%$ & $0,039 \%$ & 0,010 & TBMS & $0,02 \%$ & $0,000 \%$ & 0,000 \\
\hline BRNA & $3,17 \%$ & $0,021 \%$ & 0,018 & ICBP & $13,03 \%$ & $0,168 \%$ & 0,156 & PGLI & $0,33 \%$ & $0,005 \%$ & 0,001 & TLKM & $0,49 \%$ & $0,006 \%$ & 0,004 \\
\hline BTEK & $41,00 \%$ & $0,004 \%$ & 0,005 & IGAR & $0,35 \%$ & $0,002 \%$ & 0,006 & SAME & $1,51 \%$ & $0,042 \%$ & 0,015 & TOTL & $0,01 \%$ & $0,000 \%$ & 0,000 \\
\hline CEKA & $28,00 \%$ & $0,004 \%$ & 0,002 & IIKP & $0,26 \%$ & $0,004 \%$ & 0,005 & SCCO & $2,99 \%$ & $0,040 \%$ & 0,030 & TPIA & $3,51 \%$ & $0,153 \%$ & 0,011 \\
\hline CSAP & $2,34 \%$ & $0,024 \%$ & 0,016 & INAF & $0,67 \%$ & $0,023 \%$ & 0,020 & SDMU & $15,00 \%$ & $0,002 \%$ & 0,002 & ULTJ & $1,77 \%$ & $0,030 \%$ & 0,014 \\
\hline СТTH & $33,00 \%$ & $0,002 \%$ & 0,002 & INAI & $5,56 \%$ & $0,162 \%$ & 0,034 & SIMA & $9,00 \%$ & $0,001 \%$ & 0,000 & UNVR & $4,55 \%$ & $0,067 \%$ & 0,029 \\
\hline DSFI & $78,00 \%$ & $0,011 \%$ & 0,010 & ITMA & $0,30 \%$ & $0,031 \%$ & 0,006 & SKBM & $0,30 \%$ & $0,003 \%$ & 0,000 & VOKS & $0,29 \%$ & $0,004 \%$ & 0,001 \\
\hline EKAD & $10,88 \%$ & $0,075 \%$ & 0,114 & KAEF & $0,17 \%$ & $0,003 \%$ & 0,004 & SMDR & $1,65 \%$ & $0,183 \%$ & 0,013 & WICO & $0,52 \%$ & $0,020 \%$ & 0,008 \\
\hline ELSA & $1,07 \%$ & $0,014 \%$ & 0,006 & KBLM & $0,01 \%$ & $0,000 \%$ & 0,000 & & & & & & & & \\
\hline \multirow{4}{*}{ Portc } & & \multicolumn{2}{|l|}{ Total Wi } & & & & & & & & & & & & $100 \%$ \\
\hline & ofo & \multicolumn{3}{|c|}{ Total E(Ri) tiap bulan } & & & & & & & & & & & $2,62 \%$ \\
\hline & & \multicolumn{3}{|c|}{ Total E(Ri) tiap tahun } & & & & & & & & & & & $31,50 \%$ \\
\hline & & & & & & & & & & & & & 0,7855 \\
\hline
\end{tabular}

TABLE 7: ISSI Optimal Stock Portfolio Performance and Market Performance in 2018 (Source: processed by writer).

\begin{tabular}{|l|c|c|}
\hline \multicolumn{1}{|c|}{ Performance } & Portfolio & Market \\
\hline Expected Return [E(R)] & $-0,022$ & $-0,012$ \\
\hline Standar Deviasi [SD] & 0,054 & 0,024 \\
\hline Rf [Risk free] & 0,005 & 0,005 \\
\hline Sp & $-0,495$ & $-0,708$ \\
\hline
\end{tabular}

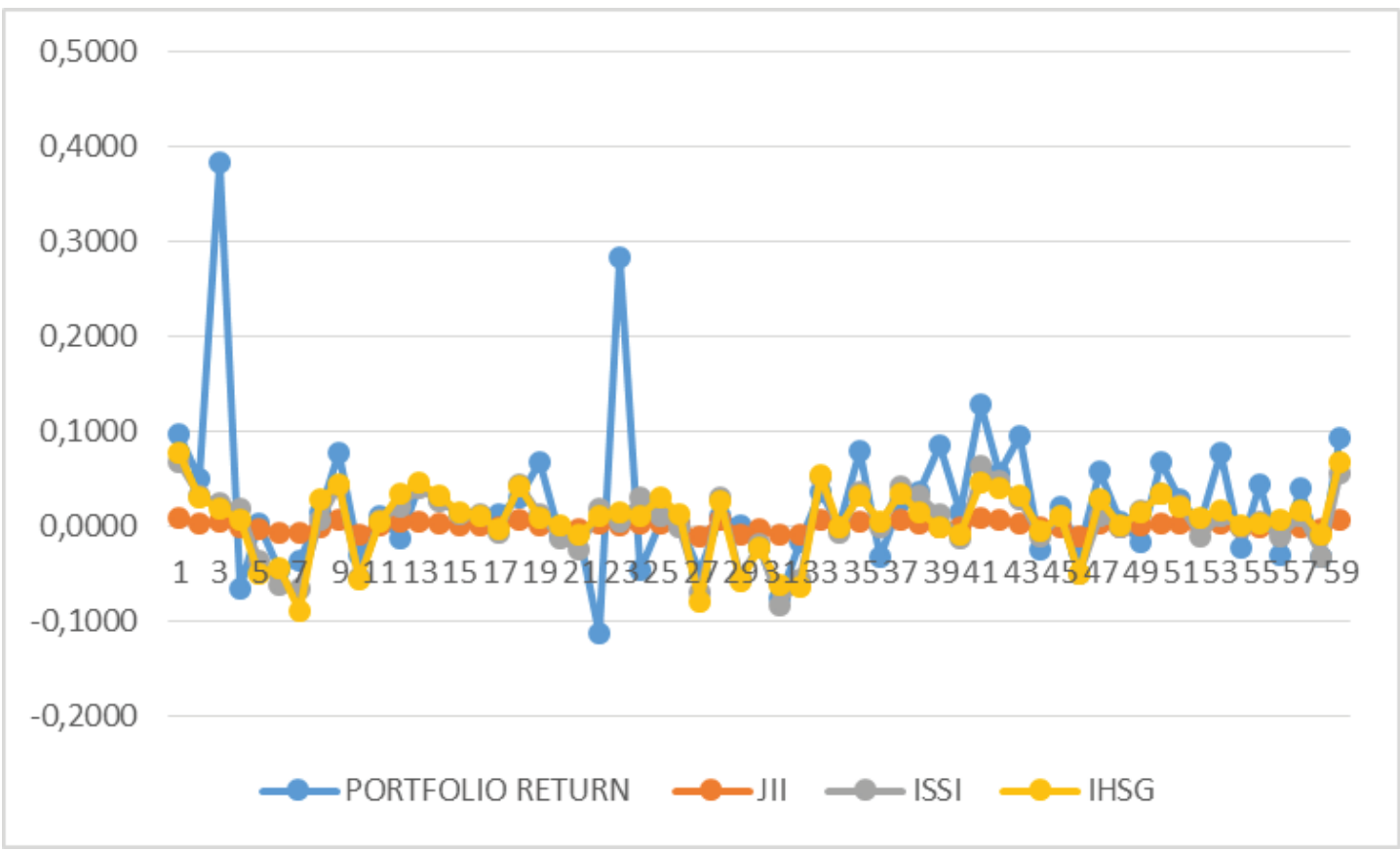

Figure 1: Comparison of Portfolio Performance (Source: Monthly portfolio and index return data processed, Ms. Excel). 
TABLE 8: Expected Return and Standard Deviation between Portfolio Shares, ISSI, JII, and IHSG Stocks for 2013-2017 (Source: Data processed by the authors).

\begin{tabular}{|l|c|c|c|c|}
\hline & ISSI & JII & IHSG & Portfolio \\
\hline $\mathbf{E}(\mathbf{R i})$ & 0,0048 & 0,0006 & 0,0067 & 0,0262 \\
\hline $\boldsymbol{\sigma i}$ & 0,0346 & 0,0049 & 0,0350 & 0,0275 \\
\hline
\end{tabular}

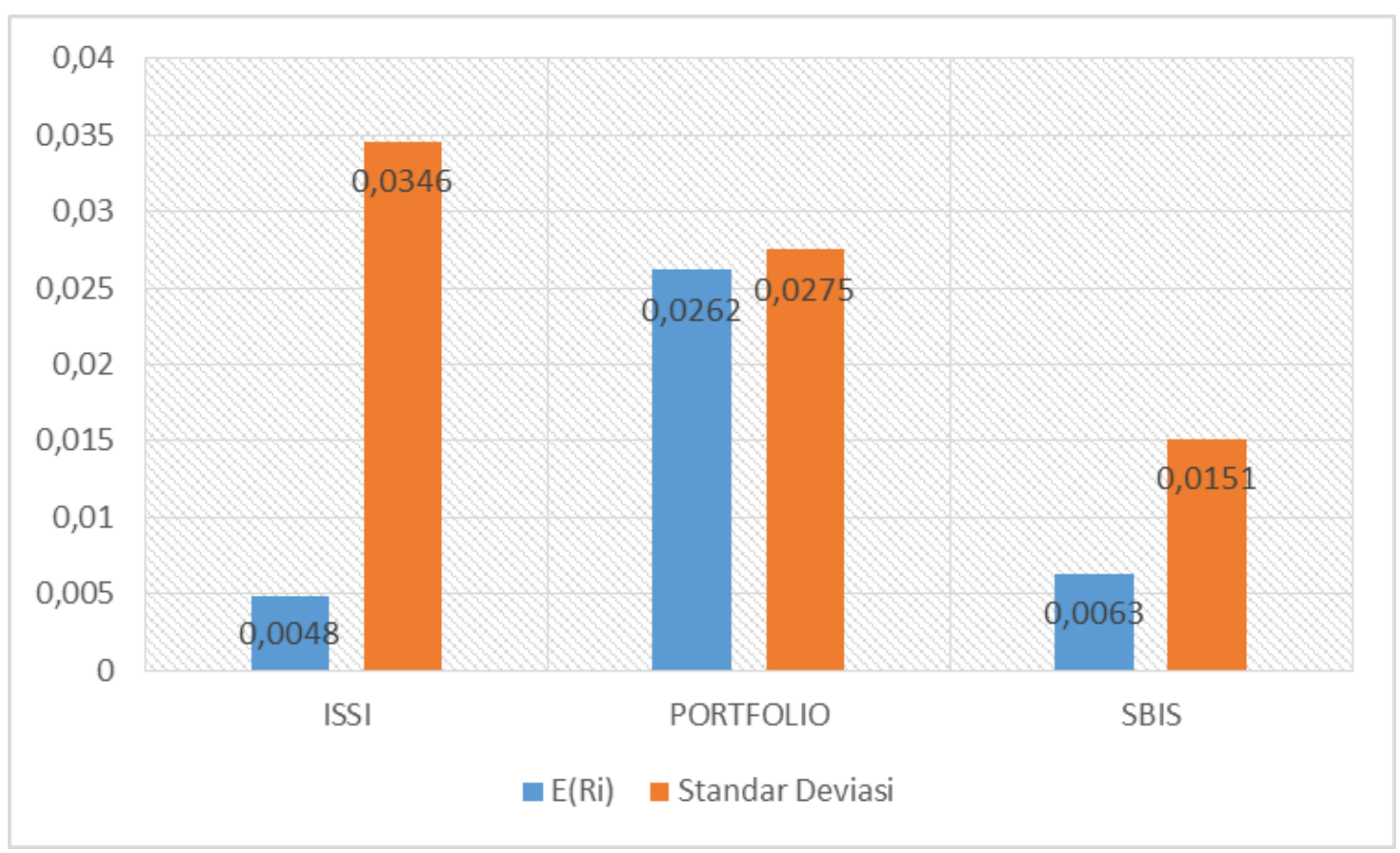

Figure 2: Comparison Return and Risk (Source: processed by author).

phenomenon, it is explained that the portfolio formed in 2013-2017 will be good in generating returns.

\subsection{Optimal portfolio performance}

Based on the results of the study prove that returns high do not necessarily have good performance. Portfolio and the market has return negative with market returns greater than portfolio returns, means that portfolio and market returns in 2018 have decreased overall stock prices due to external factors. Although portfolio risk is greater than market risk, the performance produced by the portfolio is higher than market performance even though both are negative. This is because the risk described by the market standard deviation is 0.024 , which has a difference with the return market of $3.6 \%$ while the return portfolio with portfolio risk is $7.6 \%$ difference. 


\section{Conclusion}

1. Stocks form an optimal portfolio based on active shares in ISSI for the period January 2013-December 2017, out of 366 listed shares produced 58 shares which formed the optimal portfolio along with the proportion of funds for each share. The formed portfolio gives an expected return of $2.62 \%$ per month or $31.44 \%$ per year. The portfolio beta value is 0.79 with a standard deviation value of 0.0275 . ISSI stock portfolio formation period of 2013-2017 with a single index models produce return a higher than the return ISSI, Jakarta Islamic Index ( JII), and JCI Index.

2. Portfolio performance as measured by the index sharpe for January 2018-October 2018 produces a value of -0.495 , while market performance produces a value of -0.708 , the index sharpe portfolio is higher than the index sharpe market even though both are negative. Based on the results of the study prove that returns high do not necessarily have good performance. Stock portfolio formed are returns lower than return, the market however the resulting higher risk than market risk. The resulting portfolio performance is higher than market performance. So, in this study the portfolio formed in 2013-2017 was good in the 2018 period, so investors or investment managers could make this portfolio a consideration in investing.

\section{References}

[1] Agency (Bapepam LK) Capital Market and Financial Institution Supervisors. 2018. Capital Market and Financial Institution Supervisory Agency. (Download on April 23, 2018). Available at http://www.bapepam.go.id/syariah/publikasi/riset/pdf/KajianMinat-Investor-Terhadap-Efek-Syariah-Di-Pasar-Modal.pdf. (BEI)

[2] Bakhoirudin, Muh. Tri. 2015. Pemilihan Saham Syariah yang Efisien Untuk Pembentukan Portofolio Optimal Melalui Pendekatan Data Envelopment Analysis (DEA) dan Single Index Model Serta Evaluasi Portofolio yang Dihasikan. Jurnal Bisnis Islam, No. 1, March, page 46-77.

[3] Bursa Efek Indonesia. 2018. Data factbook Bursa Efek Indonesia tahun 2018. Bursa Efek Indonesia.

[4] Bursa Efek Indonesia. 2018. Data Statistik Bursa Efek Indonesia tahun 2018. Bursa Efek Indonesia.

[5] Elton, Edwin J, Martin J, Gruber, and Manfred W. Padberg. 1995. Risk Reduction and Portfolio Size: An Analytical Solution. Journal of Business 50: 415-37. 
[6] 1995, Modern Portfolio Theory and Investment Analysis, Fifth Edition, John Wiley \& Sons, Inc. Toronto, Canada.

[7] Halim, Abdul. 2005. Analisis Investasi. Jakarta: Salemba Empat

[8] Husnan, S. 2003. Dasar-dasar Teori Portofolio dan Analisis Sekuritas. Yogyakarta: AMP YKPN.

[9] Ivanova, M. And L. Dospatliev. 2017. Application of Markowitz Portfolio Optimization on Bulgarian Stock Market From 2013 to 2016, International Journal of Pure and Applied Mathematics, Vol. 117, No. 2, page 291-307

[10] Jogiyanto, Hartono. 2010. Teori Portofolio dan Analisis Investasi. Yogyakarta: BPFE

[11] Kulali, Ihsan. 2016. Portfolio Optimization Analysis with Markowitz Quadratic MeanVariance Model, European Journal of Business and Management, Vol. 8, No. 7, page 73-79

[12] National Sharia Council (DSN) Indonesian Ulema Council (MUI), Fatwa of the National Sharia Council of the Indonesian Ulema Council No. 20 / DSN-MUI / IX / 2000 concerning Investment Implementation Guidelines for Sharia Mutual Funds, Jakarta; 2000

[13] Sarker, Mokta Rani. 2013. Markowitz Portfolio Model: Evidence From Dhaka Stock Exchange in Bangladesh, Vol. 8, Issue 6, page 68-73

[14] Tandelilin, Eduardus. 2010. Portofolio dan Investasi. Yogyakarta: Kanisius

[15] Van Horne, James C. 1997. Prinsip-Prinsip Manajemen Keuangan, Jakarta: Salemba Empat.

[16] Yuniarti, Sari. 2010. Pembentukan Portofolio Optimal Saham-Saham Perbankan dengan Menggunakan Model Indeks Tunggal, Jurnal Keuangan dan Perbankan, Vol. 14, No. 3, September

[17] www.bi.go.id. accessed November 23, 2018.

[18] www.dunia.investasi.com. accessed November 22, 2018

[19] www.e-bursa.com. accessed November 22, 2018 